\title{
Sosialisasi Pemanfaatan Energi Terbarukan Dan Pelatihan Teknologi Tepat Guna Berbasis Solarcell Untuk Pelajar SMPIT Ibnu Sina Merauke
}

\author{
Muhamad Rusdi*1, Hariyanto ${ }^{2}$, Cipto $^{3}$ \\ ${ }^{1}$ Program Studi Teknik Elektro, Fakultas Teknik, Universitas Musamus, Indonesia \\ 2,3Program Studi Teknik Mesin, Fakultas Teknik, Universitas Musamus, Indonesia \\ *e-mail: rusdi_ft@unmus.ac.id ${ }_{2}{ }_{2}$ hariyanto_ft@unmus.ac.id ${ }_{2}{ }_{2}$ cipto@unmus.ac.id ${ }^{3}$
}

\begin{abstract}
Abstrak
Konservasi energi merupakan langkah pemerintah untuk melestarikan sumber daya energi. Mengingat kebutuhan energi saat ini sebagian besar masih ditopang oleh energi fosil. Energi fosil adalah sumber daya alam seperti gas alam, batu bara dan minyak bumi yang semakin berkurang jumlahnya. Penggunaan energi fosil juga dapat menimbulkan polusi dan kerusakan alam yang signifikan. Energi terbarukan adalah energi ramah lingkungan yang menjadi topik bahasan belakang ini sebagai pengganti energi fosil. Namun, pemanfaatan energi terbarukan masih belum banyak diketahui masyarakat. Kesadaran dan perilaku hemat energi pada masyarakat juga masih kurang. Perlunya sosialisasi dan penyuluhan sejak dini kepada masyarakat sebagai sarana untuk mendukung langkah pemerintah dalam konservasi energi dan pemanfaatan energi terbarukan. Dengan program pengabdian kepada masyarakat dana hibah lembaga LP2M Universitas Musamus, kami sebagai bagian dari Civitas akademik kampus Universitas Musamus melakukan program Pengabdian Kemitraan Masyarakat (PKM) sebagai sarana dalam membantu permasalahan tersebut. Kegiatan pengabdian masyarakat ini dilakukan di SMPIT Ibnu Sina Merauke sebagai mitra dan langkah awal sosialisasi masyarakat sejak dini. Adapun teknis kegiatan ini dilakukan dengan memberikan sosialisasi dan penyuluhan tentang pentingnya konservasi energi dan pemanfaatan energi terbarukan. Selain itu, kegiatan ini juga meliputi pelatihan Teknologi tepat guna berbasis solar cell guna meningkatkan minat dan softskill peserta. Hasil evaluasi yang dilakukan mencapai 53\% dari akurasi evaluasi tingkat pemahaman peserta mengenai perilaku hemat energi dan teknologi tepat guna berbasis energi terbarukan.
\end{abstract}

Kata kunci: Energi Terbarukan, Konservasi Energi, Solar Cell, Teknologi Tepat Guna.

\begin{abstract}
Energy conservation is a government step to conserve energy resources. Current energy needs are still largely supported by fossil energy. Fossil energy refers to natural resources such as natural gas, coal and petroleum, which have fewer errors. The use of fossil energy can also cause significant pollution and natural damage. Renewable energy is environmentally friendly energy which is the topic of discussion as fossil energy. However, the use of renewable energy is still unknown to the public. There is also a lack of awareness and energy-saving behavior in the community. The need for early socialization and outreach to the community as a means to support government steps in energy conservation and utilization of renewable energy. With a community service program with a grant from the Musamus University LP2M institution, we as part of the Musamus University campus academic community carry out the Community Partnership Service (PKM) program as a means of helping these problems. This community service activity was carried out at SMPIT Ibnu Sina Merauke as a partner and the first step in community socialization from an early age. The technical technicalities of this activity are carried out by providing socialization and counseling on the importance of energy conservation and the use of renewable energy. In addition, this activity also includes training on appropriate technology based on solar cells to increase interest and soft skills participants. The results of the evaluation reached 53\% of the evaluation of the level of understanding of the participants regarding the behavior of energy and appropriate technology based on energy.
\end{abstract}

Keywords: Appropriate Technology, Energy Conservation, Renewable Energy, Solar Cell.

\section{PENDAHULUAN}

Penggunaan energi fosil masih menjadi pemasok utama pembangkit listrik ataupun transportasi yang digunakan untuk saat ini dikarenakan meningkatnya aktifitas dan kebutuhan manusia. Namun, energi fosil juga berperan dalam meningkatkan polusi udara dan mengakibat kerusakan alam yang cukup besar. Permasalahan yang ditimbulkan karena penggunaan energi 
fosil mendorong negara-negara berkembang untuk melakukan penelitian mengenai sumber energi yang lebih ramah lingkungan. Pemanfaatan energi terbarukan saat ini berkembang pesat sebagai pembangkit listrik dengan memanfaatkan energi surya, angin, air dan panas bumi [1]. Salah satu pemanfaatan energi terbarukan yang banyak digunakan dan sesuai dengan potensi di Kabupaten Merauke yaitu angin dan surya. Khususnya energi surya, Kabupaten Merauke memiliki $800-2000 \mathrm{~W} / \mathrm{m} 2$ rata-rata radiasi energi matahari yang dihasilkan dengan $10-14 \mathrm{~W}$ daya listrik konstan [2]. Pemanfaatan energi surya dapat dilakukan dengan menggunakan solar cell yang berfungsi sebagai piranti yang mengkonversi energi surya menjadi energi listrik atau sebagai pembangkit energi listrik tenaga surya (PLTS) [3][4][5]. Dimana PLTS banyak diaplikasikan pada skala rumah sebagai pemasok utama energi listrik atau mode terhubung jaringan PLN [3][6]. Pada skala yang lebih kecil Solar Cell juga dapat diterapkan sebagai pengisi daya baterai Handphone [7][8][9].

Persoalan diatas menunjukkan bagaimana perlunya kesadaran masyarakat tentang perilaku hemat energi dan meningkatkan wawasan masyarakat mengenai peran penting energi terbarukan dalam penghematan energi dan penerapannya dalam kehidupan sehari-hari. Peralihan energi bukan hal yang mustahil dilakukan untuk membangun desa ataupun kota mandiri energi. Terlebih lagi didukung dengan adanya kebijakan pemerintah tentang pemanfaatan energi terbarukan. Hal tersebut perlu didorong dengan melakukan sosialisasi dan pelatihan kepada masyarakat[10]. Selain itu, pemerintah melalui Kementerian ESDM telah melakukan sosialisasi mengenai konservasi energi dilingkungan sekolah guna menanamkan paradigma berperilaku hemat energi sejak dini [11].

Pengabdian kemitraan masyarakat dengan mengadakan sosialisasi tentang peran energi terbarukan dalam mewujudkan desa ataupun kota mandiri energi serta memberikan pelatihan atau workshop yaitu pemanfaatan energi terbarukan berbasis solar cell sebagai media charger handphone. Kegiatan ini dilaksanakan disekolah SMPIT IBNU SINA Merauke dalam upaya atau langkah yang dilakukan untuk mengurangi ketergantungan terhadap energi fosil dan menanamkan kesadaran perilaku hemat energi sejak dini.

\section{METODE}

Metode pelaksanaan yang digunakan pada pengabdian ini terdiri dari 3 tahapan yaitu : Diskusi dan Observasi, Sosialisasi dan penyuluhan, Pelatihan dan Perancangan produk. Adapun uraian dari tahapan-tahapan tersebut adalah sebagai berikut :

1) Metode Diskusi dan Observasi : Pengabdian ini diawali dengan proses komunikasi dengan kepala sekolah dari SMPIT Ibnu Sina Merauke untuk memperoleh informasi dan perijinan dari mitra untuk melakukan peninjauan lokasi.

2) Metode Sosialisasi dan penyuluhan : Memberikan sosialisasi kegiatan dengan menjelaskan tahapan-tahapan dari kegiatan yang dilakukan. Memberikan penyuluhan tentang pentingnya perilaku hemat energi dan pemanfaatan energi terbarukan.

3) Metode Praktik dan Drill : Setelah penyuluhan, pemberian materi dan demonstrasi diberikan peserta diberikan pelatihan dengan mempraktekkan langsung sesuai dengan materi dan demonstrasi yang diberikan. Hal tersebut dilakukan untuk membantu peserta dalam memahami materi. Kegiatan pelatihan meliputi pengenalan bahan dan peralatan yang digunakan dalam melakukan perancangan produk (Teknologi tepat guna berbasis solar cell).

Tabel 1. Jadwal Pelaksanaan Pengabdian

\begin{tabular}{lc}
\hline \multicolumn{1}{c}{ Jenis Kegiatan } & Waktu \\
\hline Survei dan analisis situasi & 28 September 2020 \\
Sosialisasi Pemanfaatan energi terbarukan & 14 Oktober 2020 \\
Pelatihan Pemanfaatan energi surya berbasis solar cell & 15 Oktober 2020 \\
Evaluasi \& Monitoring & 19 Oktober 2020 \\
\hline
\end{tabular}


Adapun kegiatan pengabdian ini dilaksanakan selama 2 bulan yaitu dari bulan September sampai Oktober 2020 bertempat di SMPIT Ibnu Sina Merauke. Tabel 1 menunjukkan jadwal kegiatan pengabdian kepada masyarakat (PKM).

Kegiatan pengabdian dilaksanakan dalam beberapa tahapan pelaksanaan dimulai pada tanggal 28 September 2020 dengan kegiatan yaitu survei dan analisis situsi yang berupa proses komunikasi dengan mitra khususnya kepala sekolah SMPIT Ibnu Sina Merauke guna memperoleh informasi baik itu berupa kebutuhan mitra maupun permasalahan mitra dan perizinan untuk melaksanakan kegiatan pengabdian kepada masyarakat. Selanjutnya, pelaksanaan kegiatan yang dilakukan yaitu sosialisasi pemanfaatan energi terbarukan pada tanggal 14 Oktober 2020 dan dilanjutkan dengan pelatihan pemanfaatan energi surya berbasis solar cell pada tanggal 15 Oktober 2020. Evaluasi dan monitoring kegiatan pengabdian dilaksanakan pada tanggal 19 Oktober 2020 berupa pemberian kuis atau soal mengenai pemanfaatan energi terbarukan dan konservasi energi.

\section{HASIL DAN PEMBAHASAN}

\section{a. Pelaksanaan Kegiatan}

Tahapan Pelaksanaan ini dibagi dalam beberapa tahapan yang disusun berdasarkan urutan kegiatan pengabdian yang telah dilakukan. Adapun tahapan pelaksanaan yaitu :

- Sosialisasi Pemanfaatan Energi Terbarukan

Sosialisasi Pemanfaatan Energi Terbarukan dilakukan dengan menggunakan media online (Seminar Online) melalui Google meet seperti yang di tunjukkan pada gambar 2. Hal tersebut untuk sebisa mungkin menghindari kerumunan atau kontak langsung akibat mewabahnya Covid-19 yang melanda Indonesia. Kegiatan ini diikuti oleh Guru dan Murid SMPIT Ibnu Sina Merauke. Materi Sosialisasi menyangkut tentang krisis energi, pengenalan sumber energi terbarukan, pemanfaatan energi terbarukan dan konservasi energi.

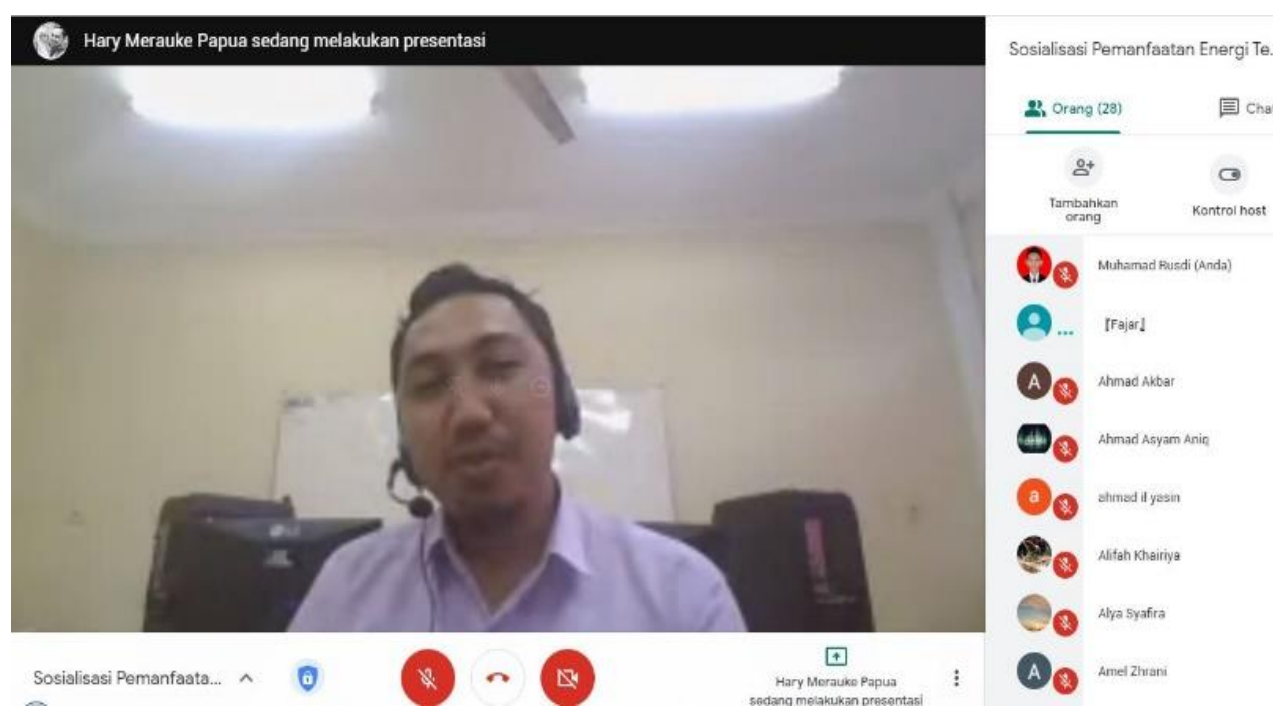

Gambar 2. Kegiatan Sosialisasi Pemanfaatan Energi Terbarukan (Seminar Online).

- Pelatihan Pemanfaatan Energi Terbarukan Berbasis Solar Cell

Modul training solar cell sebagai media charger handphone merupakan produk Teknologi Tepat Guna (TTG) yang dapat digunakan sebagai bahan praktek bagi siswa-siswi atau peserta pada program pengadian ini. Diharapkan dengan adanya sosialisasi dan pelatihan ini dapat meningkatkan perilaku hemat energi dan mengenalkan mereka tentang pemanfaatan energi terbarukan khusus energi matahari. 
Gambar 3 menunjukkan skematik dan prinsip kerja dari modul training solar cell sebagai media charger handphone yaitu memanfaatkan energi matahari untuk menghasilkan energi listrik dengan menggunakan solar cell. Energi listrik yang dihasilkan solar cell kemudian melalui komponen IC 7805 untuk membatasi tegangan yang keluar sesuai dengan spesifikasi tegangan pada handphone.
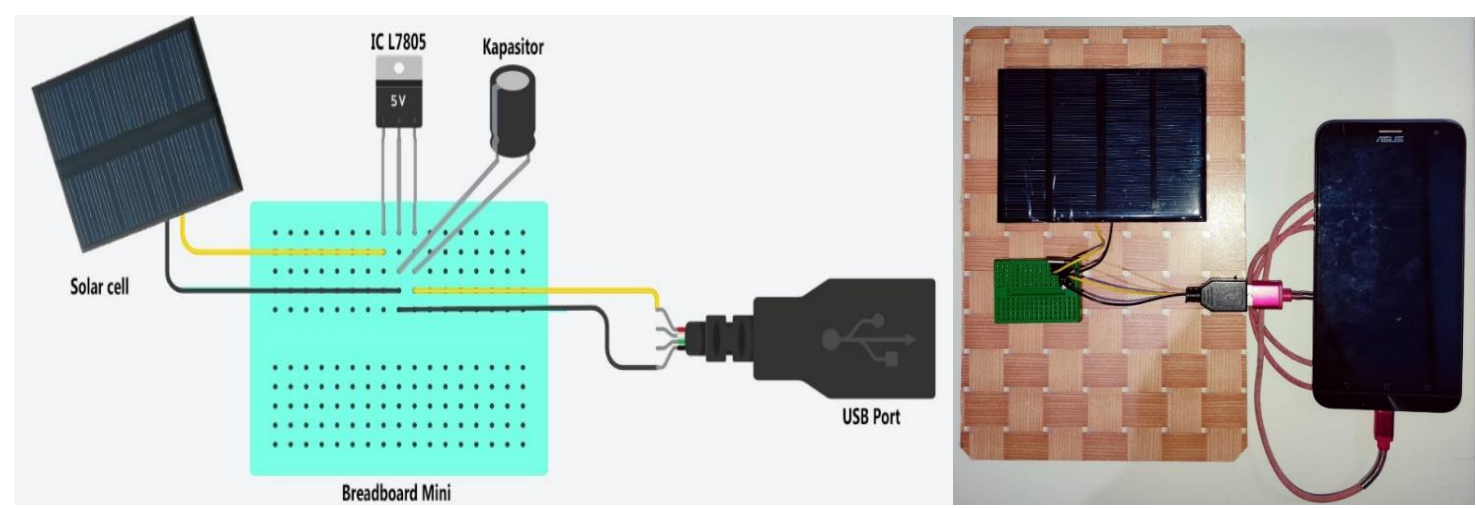

Gambar 3. Skematik \& Instalasi Modul training solar cell sebagai media charger handphone.

Pada Pelatihan ini Peserta Dibagi menjadi 5 Kelompok yang terdiri dari 5 orang seperti yang diperlihatkan pada gambar 4. Tentunya Kegiatan Pelatihan ini disesuaikan dengan standar pencegahan covid-19. Dimana peserta diwajibkan untuk menggunakan masker handsanitizer/mencuci tangan sebelum memasuki ruangan. Hasil dari perakitan modul training kemudian diuji coba oleh peserta seperti yang ditunjukkan pada gambar 5 .

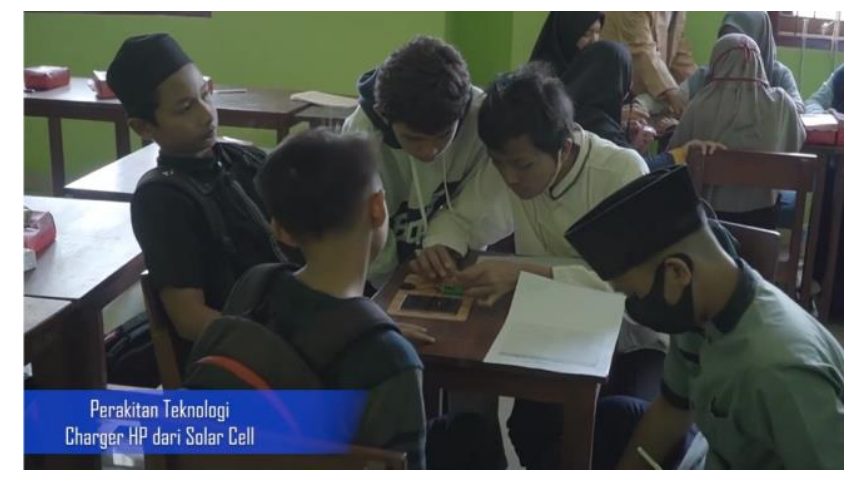

Gambar 4. Perakitan Modul training solar cell sebagai media charger handphone.

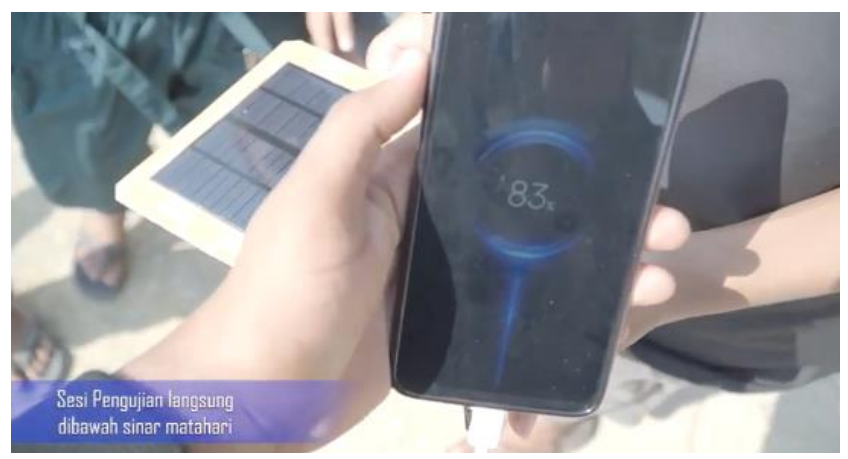

Gambar 5. Pengujian Modul training solar cell sebagai media charger handphone. 


\section{b. Monitoring \& Evaluasi}

Pada Tahapan ini bertujuan untuk mengevaluasi hasil dari kegiatan pengabdian yang telah dilakukan. Evaluasi tingkat pemahaman peserta mengenai pemanfaatan energi terbarukan dengan melakukan uji/kuis yang dilakukan secara online melalui Quizizz.com. Penilaian di lakukan pada 15 peserta yang mengikuti evaluasi dengan hasil yang di peroleh sebesar $53 \%$ akurasi peserta menjawab soal dengan benar 3 dari 5 soal yang diberikan seperti yang ditunjukkan pada gambar 6.

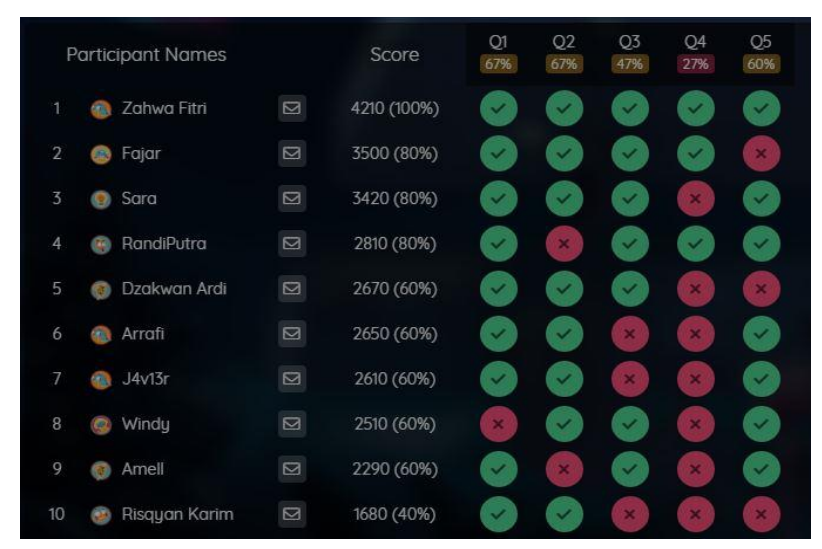

Gambar 6. Daftar 10 Besar Peserta yang mengikuti Kuis.

\section{KESIMPULAN}

Simpulan Sosialisasi dan pelatihan pemanfaatan energy terbarukan di SMPIT Ibnu Sina Merauke telah terlaksana. Peserta Sosialisasi dan pelatihan memahami dan mampu dalam menerapkan pemanfaatan energy terbarukan. Selain itu, menambah kesadaran peserta dalam berperilaku hemat energi dengan hasil 53\% dari akurasi evaluasi pemahaman peserta. Adanya Teknologi Tepat Guna berbasis solar cell sebagai luaran yang dapat menjadi bahan pembelajaran mengenai pemanfaatan energy terbarukan.

\section{UCAPAN TERIMA KASIH}

Penulis Mengucapkan terima kasih kepada pihak yang telah berkontribusi dalam terlaksananya program pengabdian kepada masyarakat ini. Khususnya kepada pihak dari SMPIT IBNU SINA Merauke sebagai mitra pengabdian dan Universitas Musamus Merauke melalui Lembaga Penelitian dan Pengabdian Masyarakat (LP2M) dalam hal pendanaan kegiatan pengabdian kepada masyarakat.

\section{DAFTAR PUSTAKA}

[1] IESR, "Energi kita," Institute for Essential Services Reform (IESR), no. November, 2019.

[2] D. Hardiantono and F. H. Sumbung, "Rancang Bangun Unit Pembangkitan Dan Modul Pengukurannya Untuk Pembangkit Listrik Tenaga Hybrid (Angin Dan Matahari)," Mustek Anim Ha, vol. 5, no. 3, pp. 231-245, 2016, doi: 10.35724/mustek.v5i3.629.

[3] M. Rusdi, F. A. Samman, and R. S. Sadjad, "FPGA-based electronic pulse generator for single-phase DC/AC inverter," in 2019 International Conference on Information and Communications Technology, ICOIACT 2019, pp. 756-760, 2019, doi: 10.1109/ICOIACT46704.2019.8938571.

[4] W. H. Piarah, Z. Djafar, Hariyanto, and Mustofa, "A new simulation of photovoltaic and 
thermoelectric generator hybrid system with a beam splitter cold and hot mirror for low intensity," Int. Rev. Mech. Eng., vol. 13, no. 9, pp. 559-567, 2019, doi: 10.15866/ireme.v13i9.17884.

[5] M. Rusdi, F. A. Samman, R. S. Sadjad, A. E. Umraeni Salam, and C. Machbub, "Standalone Single Phase DC-AC Inverter with FPGA-based Pulse Modulated Generator Unit," in 2020 International Seminar on Intelligent Technology and Its Applications (ISITIA), pp. 7-12, Jul. 2020, doi: 10.1109/ISITIA49792.2020.9163770.

[6] Z. Fuadi, M. Ashari, F. A. P, and A. Photovoltaic, "Perancangan dan Simulasi Full Bridge Inverter Lima Tingkat dengan Dual Buck Converter Terhubung Jaringan Satu Fasa," J. Tek. Pomits, vol. 3, no. 1, pp. 2337-3539 (2301-9271), 2014.

[7] W. Rotib, "Aplikasi Sel Surya Sebagai Energi Alternatif," Inst. Sci. Technol. Stud., vol. 4 no.1, pp. 1-8, 2001.

[8] G. R. F. S. Sugeng Haryadi, “Rancang Bangun Pemanfaatan Panel Surya Sebagai Charger Handphone Di Tempat Umum," Tek. mesin UNISKA, vol. 02, no. 02, pp. 114-120, 2016.

[9] S. Hidayat, "Pengisi Baterai Portable Dengan Menggunakan Sel Surya," J. Energi Kelistrikan, vol. 7, no. 2, pp. 137-143, 2015.

[10] H. Prasetijo, A. Fadli, P. B. Santoso, and W. H. Purnomo, "Workshop Penggunaan Microsoft Office Sebagai Penunjang Keterampilan Hard Skill Siswa Pendidikan Dasar," Jurnal Pengabdian Masyarakat Indonesia (JPMI), vol. 1, no. 1, pp. 7-15, 2021.

[11] I. D. Kosambi, R. A. Diantari, T. Darmana, and S. Hidayat, "Sosialisasi Energi Baru Terbarukan Untuk Pelajar SMP Annida Al,” Terang, vol. 1, no. 2, pp. 105-112, 2019. 